\title{
Welcome to Lisbon!
}

\section{J. H. van Krieken}

Published online: 8 August 2012

(C) Springer-Verlag 2012

Most of you will read this editorial in Lisbon (I hope), on the occasion of the XVIth EAHP-SH meeting, which, like always, is promising to be the place to be for haematopathologists. The combination of symposia and workshops on lymphoid tissue and bone marrow pathology has always been an excellent way to learn and make progress. During the symposia, we hear about the state of the art and new findings on a specific topic; during the workshop, our ideas are tested by challenging cases, cases which often obviously do not follow our rules and ideas. Over time, I have learned so many things, had to change so often my ideas and developed new plans for research that I am sure that these will happen this time as well, not only for me but for everybody who wants to open his or her mind to new ideas.

I have not participated in all the EAHP meetings, but was so lucky to participate in the first one in Geneva in 1988. I remember going there by train, along the Rhine, and drinking the wine which had been made from grapes that grew along where we were travelling. It was one of my first international meetings, and I thought it was normal that news that was so groundbreaking came about: it was the meeting where the idea that extranodal lymphomas are different from nodal ones was presented by Peter Isaacson, and widely accepted, that is, in Europe. At that time, there was not a good interaction with the $\mathrm{SH}$, and the exchange of ideas between European and American opinion leaders was more of a battle than an exchange based on curiosity.

Another memorable meeting was the sixth one in Bologna (don't try to understand the numbering of the meetings; it just doesn't add up). It was the meeting where the food during lunch was phenomenal, but more important, where immunohistochemistry got a completely new dimension, partly due to new antibodies for paraffin, partly to the introduction of retrieval methods. I remember the amazing and surprising stains shown by Stephano Pileri during the workshop, stains that really resulted in important changes in diagnosis, and after that meeting, everybody stepped into a new world.

For me personally, the topic of the present meeting, $\mathrm{T}$ cell lymphomas, brings special memories back of the meeting in Leiden in 1998, which had the same topic. Much has changed since then, and it is really timely that this topic, which is a difficult one for everybody, is chosen again.

This issue of the Journal of Hematopathology contains the abstracts for the meeting. I hope you will enjoy the new science in there. It also contains the workshop report of the previous meeting in Uppsala. When I read it a few months ago for review, I realized again how wonderful and interesting this workshop had been and how much we learned. The workshop report is an excellent and very detailed reflection of that, really a reference work to go back to from time to time. Finally, the issue also contains the "normal" content of the journal with original articles, reviews, case reports and book and literature reviews. I hope you will enjoy this issue and, when you are not yet a regular reader, for you to become one.

J. H. van Krieken $(\triangle)$

Department of Pathology, Radboud University Nijmegen Medical

Centre,

P.O. Box 9101, 6500 HB Nijmegen, The Netherlands

e-mail: J.vankrieken@pathol.umcn.nl 